\title{
Current status of the threatened Olrog's Gull Larus atlanticus: global population, breeding distribution and threats
}

\author{
PABLO YORIO, PABLO PETRACCI and PABLO GARCÍA BORBOROGLU
}

\begin{abstract}
Summary
Olrog's Gull Larus atlanticus breeds only in Argentina and is currently categorized as "Vulnerable". Knowledge of the location of colonies and an updated understanding of human activities that may impact their breeding populations are crucial to the development of adequate conservation and management actions. In this paper we update the breeding distribution and abundance of Olrog's Gull, using information from three aerial surveys (2004, 2007 and 2009) in its main breeding area, Buenos Aires Province, complemented by additional nest counts in southern Chubut Province, covering its entire breeding range. We also provide an updated and more detailed account of threats faced by Olrog's Gulls at their nesting grounds, and summarise progress made towards their protection. The number of breeding sites was $7^{-12}$ per year, with locations differing among years. Five previously unrecorded breeding locations were identified. Colony size ranged from 5 to 3,540 breeding pairs, with the total breeding population 4,860-7,790 pairs, $98 \%$ of which nest in southern Buenos Aires Province. The main threats faced by breeding Olrog's Gulls include coastal development, pollution, sport fishing and unregulated tourism and recreational activities. Recent strengthening of the protected area system in Argentina has resulted in all known breeding sites, with the exception of Isla Brightman, falling within protected areas. We need comprehensive, simultaneous surveys to track global population trends. Despite enhanced protection of Olrog's Gull breeding populations, efforts are still needed to ensure that guidelines for their protection are included in management plans and that these are implemented effectively.
\end{abstract}

\section{Introduction}

Olrog's Gull Larus atlanticus breeds only in Argentina between $38^{\circ} 49^{\prime}$ and $45^{\circ} 11^{\prime} \mathrm{S}$, in colonies distributed in two coastal sectors separated by $700 \mathrm{~km}$, southern Buenos Aires Province and southern Chubut Province (Yorio et al. 1999). In winter, it disperses north along the coast of Buenos Aires Province (Favero 1991, Silva Rodriguez et al. 2005), reaching Uruguay (Escalante 1970, Aspiroz 2003) and southern Brazil (Dias and Mauricio 1998, Pacheco et al. 2009). Olrog's Gull is one of the few globally threatened Larus species. Because of its low population size, restricted distributional range, migratory behaviour, and population threats, Olrog's Gull has been recognised as "Vulnerable" (BirdLife International 2012) and listed in Appendix I of the Convention on Migratory Species.

Olrog's Gulls were first recorded nesting at Bahía San Blas $\left(40^{\circ} 32^{\prime} \mathrm{S}, 62^{\circ} 17^{\prime} \mathrm{W}\right)$, southern Buenos Aires, in 1932 (Daguerre 1933), and subsequently bred in the same area in 1963 (Olrog 1967) and 1975 (Devillers 1977). However, wide-scale surveys and colony counts were not conducted until 1990, when an estimated 1,220 breeding pairs were located in four colonies in southern Buenos Aires and one colony in southern Chubut (Yorio and Harris 1992). A subsequent survey in 1995 found seven previously unrecorded colonies, five in southern Buenos Aires Province 
and two in southern Chubut, while two of the colonies recorded in 1990 had disappeared. The total population was estimated at 2,300 breeding pairs (Yorio et al. 1997). Three additional breeding sites were found between 1998 and 2006, including the largest reported colony located on Isla del Puerto, Bahía Blanca Estuary $\left(38^{\circ} 49^{\prime} \mathrm{S}, 62^{\circ} 15^{\prime} \mathrm{W}\right.$ ) (Delhey et al. 2001a, Rábano et al. 2002, Petracci et al. 2008). These observations indicate that Olrog's Gulls can change breeding sites between years (Yorio et al. 1997, García Borboroglu and Yorio 2007a), making it difficult to assess both local and overall population trends. Systematic, simultaneous surveys are needed at the regional scale to adequately assess the population status and trends of Olrog's Gull.

Habitat modification and disturbance are growing threats to many breeding and foraging bird populations, resulting in increased concern due to rapid growth of wildlife-based tourism, recreation, and resource extraction activities (Whittacker and Knight 1998, Yorio et al. 2001b). Several studies have reported effects of these activities on coastal bird foraging, nesting habitat use, breeding success, and population numbers (e.g. Erwin et al. 2003). Olrog's Gull is highly dependent on intertidal habitats. It has a rather specialised feeding ecology during the breeding season, preying almost exclusively on crabs (Delhey et al. 2001b, Herrera et al. 2005, Suárez et al. 2011), which makes it vulnerable to changes in selective pressures and to environmental modifications resulting from human activities at its breeding grounds. In this context, knowledge of the location of colonies and an updated understanding of human activities in coastal areas that may impact Olrog's Gull breeding populations are crucial to the development of adequate conservation strategies and management actions. In this paper we update the breeding distribution and abundance of Olrog's Gull using information from three aerial surveys in southern Buenos Aires Province and additional nest counts at other breeding locations. We also summarise the threats faced by Olrog's Gulls at their nesting grounds, and report progress made towards their protection.

\section{Methods}

Aerial surveys were conducted along the coast of southern Buenos Aires Province on 6 November 2004, 26-27 October 2007, and 9-10 November 2009, during the Olrog's Gull late incubation stage. Survey dates varied among years due to inter annual differences in timing of breeding and weatherinduced restrictions on flying. The surveyed area extended from Bahia Blanca $\left(38^{\circ} 5 \mathrm{O}^{\prime} \mathrm{S}\right)$ to Bahia San Blas $\left(40^{\circ} 30^{\prime}\right.$ S) (Figure 1). Flight paths were chosen so as to include previously unsurveyed territory and locations where colonies had already been reported. A Cessna 182 was used, flying at an altitude of 100-200 $\mathrm{m}$ with observers on both sides of the plane. Known breeding sites and suitable habitat for nesting were located using a GPS and Landsat satellite images. Each colony was photographed using digital cameras (Canon $300 \mathrm{D}$ and $50 \mathrm{OD}$ ) with telephoto zoom lens (Canon 75-300 mm and $100-400 \mathrm{~mm}$ ) and the number of breeding pairs was counted from the photos, except for Isla del Puerto where nest counts during visits by boat to the island were conducted. Olrog's Gull nesting groups are easily recognised from aerial photos due to their tight nesting distribution (mean internest distance of $0.66 \mathrm{~m}$; García Borboroglu and Yorio 2007b) compared to Kelp Gulls Larus dominicanus $(2.3 \mathrm{~m})$. Nests of the two species are not intermingled, facilitating their discrimination in the aerial photos. Due to the high nest density, non-breeders rarely spend time within colony boundaries (unpubl. data). Nests were identified in the photographs based on nesting material, nest spacing and/or the presence of a sitting bird. A breeding pair was defined as any gull sitting on a nest or a pair standing at a nest. Coastal sectors in Golfo San Jorge, Chubut $\left(44^{\circ} 55^{\prime}, 60^{\circ} 32^{\prime} \mathrm{W}-45^{\circ} 13^{\prime} \mathrm{S}\right.$, $66^{\circ} 31^{\prime} \mathrm{W}$ ), where Olrog's Gulls were previously recorded breeding were visited by boat to locate colonies during the incubation or chick stages, and nest counts made.

\section{Results and Discussion}

\section{Population distribution and abundance}

Aerial surveys of the northern breeding grounds allowed the identification of four previously unrecorded breeding locations: Tres Brazas, Isla Luana, Isla Embudo, and Isla Gaviota (Figure 1). 


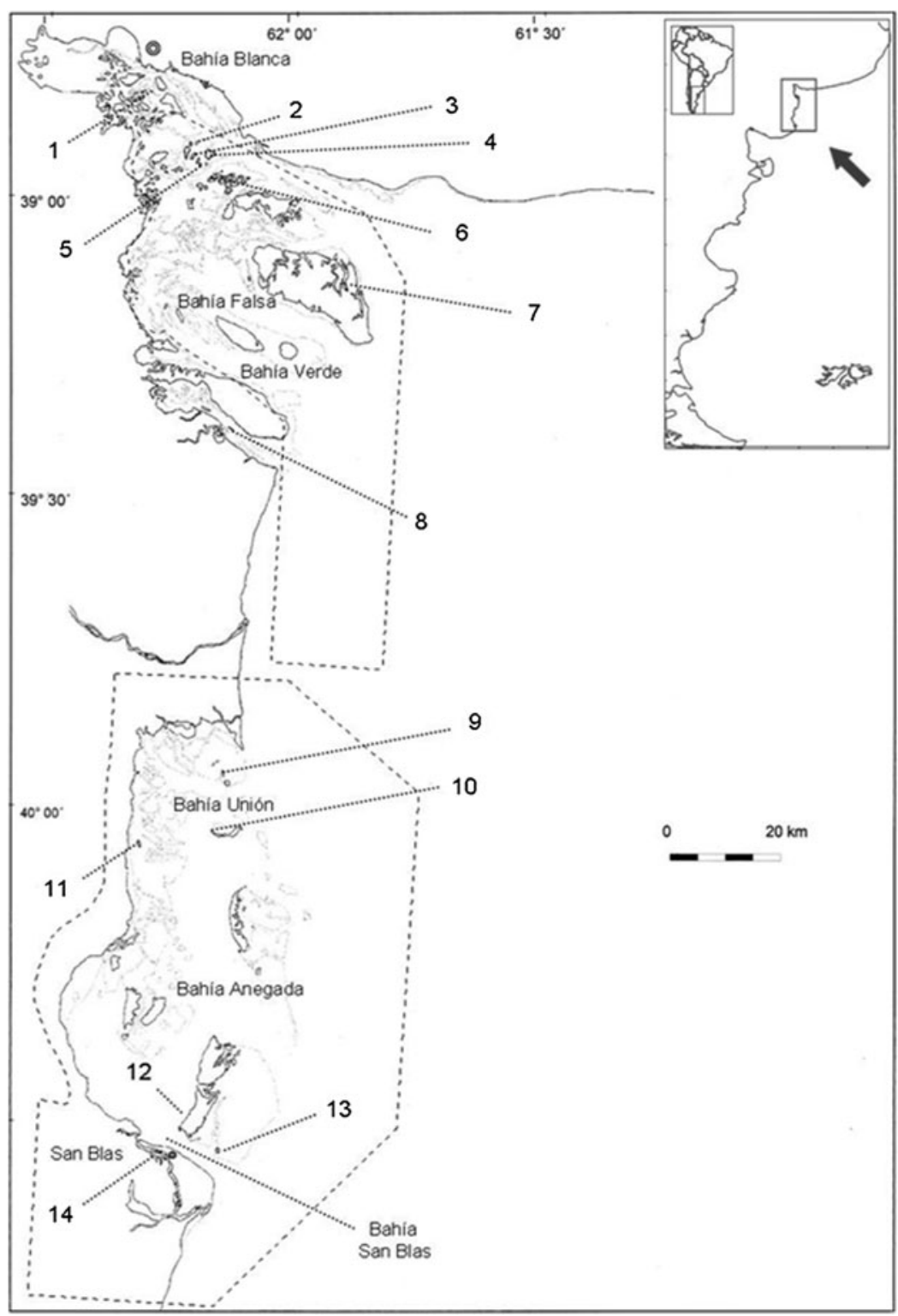

Figure 1. Location of Olrog's Gull colonies recorded along the southern coast of Buenos Aires Province, Argentina, between 1990 and 2009. Numbers correspond to site numbers in Table 1. Dotted lines indicate the extension of protected areas (Bahía Blanca, Bahía Falsa and Bahía Verde to the north and Bahía San Blas to the south). The Isla del Puerto protected area is not shown due to the scale of the map.

The number of Olrog's Gull breeding sites in southern Buenos Aires Province differed between years, with five colonies in 2004, 10 in 2007 and seven in 2009 (Table 1, Figure 1). Only four of the 14 breeding locations were active during all three aerial surveys (Isla del Puerto, Isla Gaviota, Isla Arroyo Jabalí Oeste and Banco Nordeste). Some breeding sites recorded in previous studies 
Table 1. Location and size of Olrog's Gull breeding colonies for the 2004, 2007 and 2009 breeding seasons. Lack of information indicates the location was not surveyed during that year. NC: nests not counted. Nest numbers at sites 1-14 were estimated from aerial photos and at sites $15-18$ from ground counts.

\begin{tabular}{|c|c|c|c|c|c|}
\hline & Breeding site & Location & 2004 & 2007 & 2009 \\
\hline 1 & Isla del Puerto & $38^{\circ} 49^{\prime}$ oo $^{\prime \prime} \mathrm{S}, 62^{\circ} 15^{\prime} 41^{\prime \prime} \mathrm{W}$ & 3329 & 3541 & 2037 \\
\hline 2 & Islote Tres Brazas & $38^{\circ} 54^{\prime} 42^{\prime \prime} \mathrm{S}, 62^{\circ} 12^{\prime} \mathrm{O}^{\prime \prime} \mathrm{W}$ & & 829 & \\
\hline 3 & Isla Golfada Chica & $38^{\circ} 55^{\prime} 50^{\prime \prime} \mathrm{S}, 62^{\circ} 12^{\prime} 26^{\prime \prime} \mathrm{W}$ & o & 1566 & 1515 \\
\hline 4 & Isla Luana & $38^{\circ} 56^{\prime} 04^{\prime \prime} \mathrm{S}, 62^{\circ} 10^{\prime} 25^{\prime \prime} \mathrm{W}$ & & 68 & 35 \\
\hline 5 & Islote Canal Ancla & $38^{\circ} 56^{\prime} 44^{\prime \prime} \mathrm{S}, 62^{\circ} 11^{\prime} 27^{\prime \prime} \mathrm{W}$ & o & 98 & $\mathrm{O}$ \\
\hline 6 & Isla Embudo & $38^{\circ} 58^{\prime} 48^{\prime \prime} \mathrm{S}, 62^{\circ} 11^{\prime} 25^{\prime \prime} \mathrm{W}$ & 59 & & \\
\hline \multirow[t]{5}{*}{7} & Islas Trinidad & & & & \\
\hline & Islote Norte & $39^{\circ} 08^{\prime} 29^{\prime \prime} \mathrm{S}, 61^{\circ} 53^{\prime} 06^{\prime \prime} \mathrm{W}$ & o & 23 & $\mathrm{o}$ \\
\hline & Islote Bastón & $39^{\circ} 08^{\prime} 30^{\prime \prime} \mathrm{S}, 61^{\circ} 53^{\prime} 10^{\prime \prime} \mathrm{W}$ & o & $\mathrm{O}$ & o \\
\hline & Islote Redondo & $39^{\circ} 08^{\prime} 35^{\prime \prime} \mathrm{S}, 61^{\circ} 53^{\prime} 11^{\prime \prime} \mathrm{W}$ & o & $\mathrm{o}$ & 600 \\
\hline & Islote Sur & $39^{\circ} 09^{\prime} 08^{\prime \prime} \mathrm{S}, 61^{\circ} 53^{\prime} 10^{\prime \prime} \mathrm{W}$ & $\mathrm{o}$ & o & o \\
\hline 8 & Isla Brightman & $39^{\circ} 23^{\prime} 16^{\prime \prime} \mathrm{S}, 62^{\circ} \mathrm{O} 7^{\prime} 33^{\prime \prime} \mathrm{W}$ & o & 5 & $\mathrm{o}$ \\
\hline 9 & Islote norte de Morro de Indio & $39^{\circ} 56^{\prime} \mathrm{S}, 62^{\circ} \mathrm{og}{ }^{\prime} \mathrm{W}$ & o & o & o \\
\hline 10 & Isla Gaviota & $40^{\circ} \mathrm{OI}^{\prime} 31^{\prime \prime} \mathrm{S}, 62^{\circ}{ }^{\circ} \mathrm{O}^{\prime} \mathrm{O}^{\prime \prime} \mathrm{W}$ & 802 & 939 & 373 \\
\hline 11 & Isla Puestos & $40^{\circ} \mathrm{O}^{\prime} \mathrm{O}^{\prime \prime} \mathrm{S}, 62^{\circ} 18^{\prime} 52^{\prime \prime} \mathrm{W}$ & o & o & $\mathrm{O}$ \\
\hline 12 & Isla Gama & $40^{\circ} 29^{\prime} \mathrm{S}, 62^{\circ} 14^{\prime} \mathrm{W}$ & $\mathrm{o}$ & o & o \\
\hline 13 & Isla Arroyo Jabalí Oeste & $40^{\circ} 32^{\prime} 43^{\prime \prime} \mathrm{S}, 62^{\circ} 17^{\prime} 24^{\prime \prime} \mathrm{W}$ & 500 & 542 & 329 \\
\hline 14 & Banco Nordeste & $40^{\circ} 32^{\prime} 44^{\prime \prime} \mathrm{S}, 62^{\circ} 10^{\prime} 06^{\prime \prime} \mathrm{W}$ & 173 & 217 & 350 \\
\hline \multirow[t]{3}{*}{15} & Islas Laguna & & & & \\
\hline & Islote Laguna & $45^{\circ} \mathrm{O} 2^{\prime} 24^{\prime \prime} \mathrm{S}, 65^{\circ} 52^{\prime} 42^{\prime \prime} \mathrm{W}$ & o & o & $\mathrm{O}$ \\
\hline & Islote Luisoni & $45^{\circ} \mathrm{OI}^{\prime} 45^{\prime \prime} \mathrm{S}, 65^{\circ} 52^{\prime} \mathrm{Og}{ }^{\prime \prime} \mathrm{W}$ & 51 & $\mathrm{o}$ & $\mathrm{O}$ \\
\hline 16 & Isla Sin Nombre & $45^{\circ} \mathrm{OO}^{\prime} 15^{\prime \prime} \mathrm{S}, 66^{\circ} \mathrm{O} 4^{\prime} 15^{\prime \prime} \mathrm{W}$ & & & \\
\hline 17 & Isla Felipe & $45^{\circ} 4^{\prime}{ }^{\prime \prime} 0^{\prime \prime}, 66^{\circ} 19^{\prime} 23^{\prime \prime} \mathrm{W}$ & & NC & NC \\
\hline \multirow[t]{4}{*}{18} & Islas Vernaci & & & & \\
\hline & Isla Vernaci Sudoeste & $45^{\circ} 10^{\prime} 55^{\prime \prime} \mathrm{S}, 66^{\circ} 3 \mathrm{I}^{\prime} \mathrm{O} 3^{\prime \prime} \mathrm{W}$ & $\mathrm{NC}$ & o & $\mathrm{O}$ \\
\hline & Isla Vernaci Noroeste & $45^{\circ} 10^{\prime} 23^{\prime \prime} \mathrm{S}, 66^{\circ} 30^{\prime} 43^{\prime \prime} \mathrm{W}$ & o & o & o \\
\hline & Isla Vernaci Oeste Noroeste & $45^{\circ} 10^{\prime} 16^{\prime \prime} S, 66^{\circ} 31^{\prime} 11^{\prime \prime} W$ & o & $\mathrm{NC}$ & $\mathrm{NC}$ \\
\hline Total & & & 4863 & 7794 & 5239 \\
\hline
\end{tabular}

such as Islotes Bastón, Islote Sur, Islote norte de Morro de Indio, Isla Puestos and Isla Gama (Yorio and Harris 1992, Yorio et al. 1997) were inactive during the three study years. Colony size ranged from five to 3,540 breeding pairs, with Isla del Puerto having the largest number of nests during the three study years (Table 1 ). Changes in numbers may have been partly affected by the timing of the different surveys, given the possible inter-annual variability in the onset of breeding at each location. As is always the case, the newly discovered colonies were associated with breeding Kelp Gulls (Yorio et al. 1997, García Borboroglu and Yorio 2007a, Petracci et al. 2008).

Isla del Puerto supported the largest colony throughout the species's breeding range, holding $39-68 \%$ of breeding pairs during the three study years. Numbers at this site declined by roughly $40 \%$ in 2009 relative to 2004 and 2007, but increased again in 2011 (P. Petracci unpubl. data.). Two new sites were discovered in the Zuraitas Archipelago: Islote Tres Brazas and Isla Luana (Figure 1). Isla Golfada Chica, located in the same archipelago, was inactive in 2004 but held a relatively large number of breeding pairs in 2007 and 2009 (Table 1 ). This colony also was active in 2006, when 311 nests and 640 fledglings were counted during a visit in late December (Petracci et al. 2008). The third newly discovered breeding site in this area was located on the northern shores on Isla Embudo, $4 \mathrm{~km}$ south of the site designated as Islote Canal Ancla in 2001 (Rábano et al. 2002) (Figure 1). Breeding gulls were only observed at this site in 2004 and in relatively 
small numbers (59 nests). The nearby Islote Canal Ancla breeding site did not show signs of nesting activity in 2004, suggesting that gulls may have moved between these sites.

Activity at Isla Trinidad was only significant in 2009. In that year, colony size (6oo nests) was the same order of magnitude as that recorded in 1995 (894 nests; Yorio et al. 1997). In the past, gulls in that sector nested in four different islets separated from each other by at most $1.3 \mathrm{~km}$. These islets are low and can experience flooding (D. Rábano pers. comm.), which may partly explain the limited nesting activity in two of the aerial surveys. Only a few nests were counted at Isla Brightman and in only one of the study years. This breeding site, first identified in 1990 with over 300 nests, was inactive in 1995 (Yorio et al. 1997).

This study reports the first breeding of Olrog's Gulls at Isla Gaviota (Figure 1), located in the northern sector of Bahía Anegada. This colony supported $>800$ nests in the first two surveys but declined to less than half this in 2009. A similar sized colony recorded north of Morro de Indio, $10 \mathrm{~km}$ north of Isla Gaviota, in 1995 (Yorio et al. 1997) was not found in subsequent surveys, suggesting it may be the same breeding group. No breeding was observed at Isla Puestos and Isla Gama in the three study years, sites which held colonies in 1990 and, in the former case, also in 1995 (Yorio and Harris 1990, Yorio et al. 1997). Breeding occurred in all three survey years at the two colonies located in the Bahía San Blas area, Isla Arroyo Jabalí Oeste and Banco Nordeste (Figure I), and land surveys indicated that both sites were active in 2006, 2008, 2010 and 2011 (N. Suárez and P. Yorio unpubl. data). Banco Nordeste, where Olrog's Gulls were first discovered breeding in 1932 (Daguerre 1933), is possibly the same site reported by Devillers (1977) for 1975. Colonies were also found in Banco Nordeste in 1998 and 2000 (Yorio et al. 2001a, García Borboroglu and Yorio 2007a). Breeding at Isla Arroyo Jabalí was first reported in 1963 by Olrog (1967) and probably corresponds to that reported in 1975 by Devillers (1977). In addition, breeding was recorded during four visits between 1990 and 2000 (Yorio and Harris 1992, Yorio et al. 1997, 2001a, García Borboroglu and Yorio 2007a). Numbers at Banco Nordeste increased while those at Isla Arroyo Jabalí decreased between 2007 and 2009 (Table 1 ), but overall, similar numbers of birds bred in these colonies (759 in 2007 and 679 in 2009), suggesting that changes may have resulted from the movement of breeding birds between these locations. Preliminary results show that breeders banded at Islote Arroyo Jabalí Oeste were observed nesting in Banco Nordeste in subsequent seasons (unpubl. data).

Monitoring at Golfo San Jorge between 2004 and 2009 indicated that the three previously recorded breeding sites were still active (Islas Laguna in Bahía Melo, Isla Felipe at Punta Tafor and Islas Vernaci within Caleta Malaspina; Yorio and Harris 1992, Yorio et al. 1997) (Table 1, Figure 2). The location of colonies within Caleta Malaspina varied among years, with three different islets of the Islas Vernaci complex used (García Borboroglu and Yorio 2007a). In 2005, gulls were recorded breeding at Isla Felipe and seven nests were counted at Isla Vernaci Noroeste, but no nests were found in Islas Laguna. Only the Islas Vernaci were visited in 2006, when 38 nests were recorded at Isla Vernaci Noroeste. In 2008, breeding at Golfo San Jorge was recorded at Isla Felipe and Vernaci Oeste Noroeste, and a new breeding site (Isla Sin Nombre) was discovered in late October between Bahía Melo and Punta Tafor (Figure 2). In that same season, gulls were recorded breeding at Isla Felipe and Islas Vernaci but not at Islas Laguna, suggesting they may have moved from the latter islands to the new breeding location. Unfortunately it was not possible to estimate colony sizes during most visits to these islands due to logistic constraints. However, breeding numbers were always of the same order of magnitude as those observed in previous studies (Yorio and Harris 1992, Yorio et al. 1997, García Borboroglu and Yorio 2007a), confirming that the number of pairs outside Buenos Aires Province represents $<_{2} \%$ of the global breeding population. The total global breeding population ranged between 4,863 pairs in 2004 and 7,794 pairs in 2007 (Table 1).

\section{Population threats}

The main threats faced by breeding Olrog's Gulls are coastal development, unregulated tourism and recreational activities, sport fishing, and pollution (Yorio et al. 1997). Possibly the most threatened sector is the Bahía Blanca estuary, where industries are important sources of persistent 


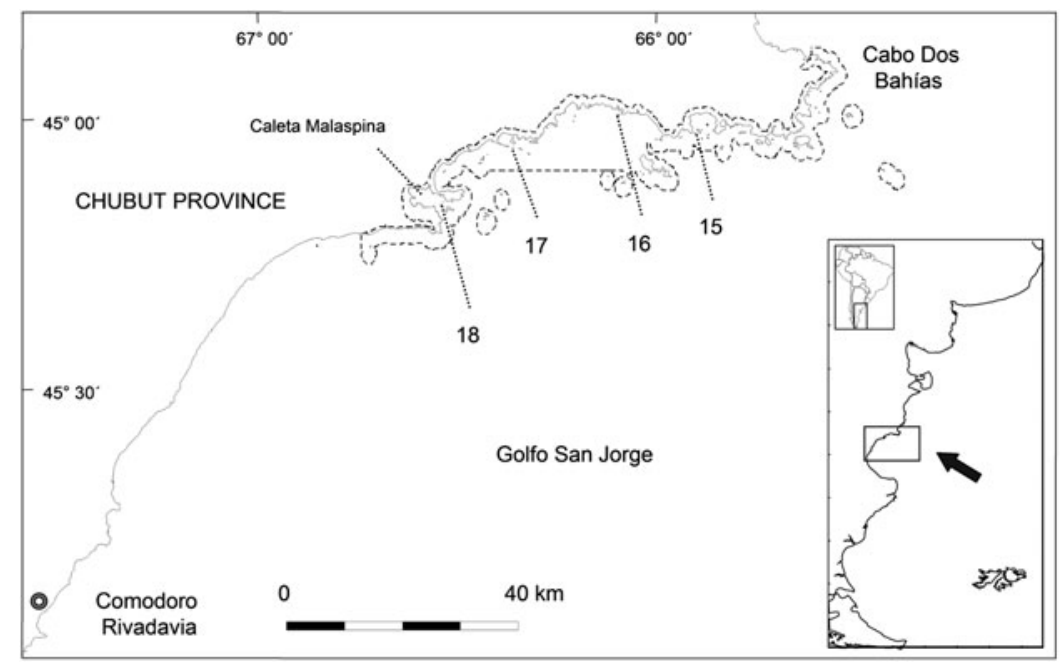

Figure 2. The distribution of Olrog's Gull colonies along the coast of Golfo San Jorge, Chubut Province, Argentina. Numbers correspond to site numbers in Table 1. Dotted lines indicate the extension of the Patagonia Austral Coastal Marine Park.

organochlorine pesticides, hydrocarbons, and heavy metals (Marcovecchio et al. 1988, Botté et al. 2008, Arias et al. 2011). Crabs, the key prey of Olrog's Gulls on their breeding grounds (Delhey et al. 2001b, Suárez et al. 2011), accumulate heavy metals and organochlorine pesticides and play an important role in the transfer of persistent pollutants to higher trophic levels (Menone et al. 2004, Beltrame et al. 2011, Simonetti et al. 2012). Mercury concentrations in Olrog's Gulls breeding at the Isla del Puerto colony were $2-17 \mu \mathrm{g} . \mathrm{g}^{-1}$ (La Sala et al. 2011), which fall within the range considered toxic to birds (Burger and Gochfeld 2002).

Olrog's Gulls in the Bahía Blanca Estuary are occasionally injured when entangled with sport fishing lines or killed following the ingestion of discarded baited hooks, as has been reported in their wintering grounds (Berón et al. 2007, Berón and Favero 2009). Harvesting of Olrog's Gull eggs at the Bahía San Blas colonies is a relatively common practice (Devillers 1977, Yorio et al. $2001 b$ ), even though these colonies are within a protected area, affecting their productivity in recent breeding seasons (N. Suárez pers. comm.). Additional potential conflicts may arise from interactions with Kelp Gulls, which breed adjacent to all known Olrog's Gull colonies (Yorio et al. 1997, García Borboroglu and Yorio 2004, this study). Kelp Gull populations have expanded in several coastal sectors of Patagonia (Yorio et al. 1998, Lisnizer et al. 2011) and preliminary information suggests that numbers in the Bahía Blanca estuary also have increased (P. Petracci unpubl. data). Kelp and Olrog's gulls share several nesting microhabitat characteristics, so an increase in the area occupied by Kelp Gulls or in their nesting density as a result of an increase in numbers could affect the availability of nesting areas for Olrog's Gulls (García Borboroglu and Yorio 2007b). Kelp Gulls also occasionally prey on Olrog's Gull chicks (La Sala and Martorelli 2010).

Conservation actions: recent improvements in the protection of breeding populations

During the last decade, progress has been made in relation to the formal protection of Olrog's Gull breeding grounds. The recent strengthening of the coastal and marine protected area system in Argentina has improved the protection status of gull breeding sites and foraging areas by creating or expanding four new protected areas: the Bahía Blanca, Bahía Falsa and Bahía Verde Multiple 
Use Nature Reserve, the Bahía San Blas Multiple Use Nature Reserve, the Isla del Puerto Reserve, and the Patagonia Austral Coastal Marine Park (Figures 1 and 2).

The Bahía Blanca, Bahía Falsa and Bahía Verde Multiple Use Nature Reserve (Figure 1), created in 1991 and expanded to include adjacent waters in 1998 (Provincial Law 12101), protects six of the breeding locations reported in the last 20 years (Islote Tres Brazas, Isla Golfada Chica, Isla Luana, Islote Canal Ancla, Isla Embudo and Isla Trinidad). The Bahía San Blas Multiple Use Nature Reserve, which includes a 4,000 km² coastal sector between Bahía Unión and Bahía San Blas, was designated as a protected area under provincial jurisdiction in 1987, and its limits expanded to include adjacent waters in 2001 (Provincial Law 12788). This protected area includes six Olrog's Gull breeding sites (Isla Norte de Morro de Indio, Isla Gaviota, Isla Puestos, Isla Gama, Isla Arroyo Jabalí Oeste and Banco Nordeste). The colonies in southern Chubut gained legal protection in 2008 due to the designation of a new marine protected area in northern Golfo San Jorge, the Patagonia Austral Coastal Marine Park (Law 26446). This recently designated marine park includes an area of $750 \mathrm{~km}^{2}$ under the joint administration of the Government of the Province of Chubut and the National Parks Administration of Argentina. Finally, the largest known Olrog's Gull colony, Isla del Puerto, was designated a protected area in 2011 (Reserva Natural Integral Isla del Puerto; Provincial Decree 469).

As a result of the extension of the areas under protection and the creation of new ones, all known breeding sites with the exception of Isla Brightman are now within protected areas. Given the relatively small foraging range of breeding Olrog's Gulls (Yorio et al. 2004, Suárez et al. 2012), these protected areas not only protect the gull's nesting sites but probably also their main feeding areas. Recently, management plan proposals have been developed and approved for the Bahía Blanca, Bahía Falsa and Bahía Verde Multiple Use Nature Reserve (Sotelo and Massola 2008; Organismo Provincial para el Desarrollo Sostenible, $N^{\circ}$ 2145-0017312/2008) and Bahía San Blas Multiple Use Nature Reserve (Zalba et al. 2008; Organismo Provincial para el Desarrollo Sostenible, $\left.\mathrm{N}^{\circ} 2145-0021084 / 2008\right)$. However, protection for Olrog's Gulls is still insufficient as two of the protected areas still do not have management plans and the ones developed for the other two areas lack formal implementation. And although existing management plans explicitly restrict access to colonies and make egg harvesting illegal, no specific conservation actions have yet been taken to address these threats. Coastal waters encompassing all of the protected areas where Olrog's Gulls breed have been also designated as Special Protection Zones, where specific regulations exist regarding the disposal of potential pollutants (Prefectura Naval Argentina 1998).

Additional conservation actions include the recent designation as Important Bird Areas of three coastal sectors with Olrog's Gull breeding sites: Bahía Blanca, Bahía Falsa and Bahía Verde (BA15), Bahía San Blas (BAi6), and Northern Golfo San Jorge (CUo5) (Di Giacomo 2005). Olrog's Gull has also recently been listed as 'Threatened' at the national level by the Secretaría de Ambiente y Desarrollo Sustentable of Argentina (Resolución $N^{\circ} 348 / 2010$ ). In 2004, the Honorable Council of the city of Bahia Blanca recognised Olrog's Gull as its emblem (Ordenanza ${ }_{12671 / 04)}$ and later as the official image of the county, reflecting the increased awareness and changed values towards Olrog's Gulls by the local community.

\section{Conclusions}

To date, Olrog's Gulls have been recorded nesting at 18 locations, although there may be less than a dozen active colonies in any given year. Our results confirm a relatively small global breeding population of less than 8,00o pairs, with more than $98 \%$ breeding in southern Buenos Aires Province. Five sites are crucial for the species: Isla del Puerto, Islas Zuraitas, Islas Trinidad, north of Bahía Anegada and Bahía San Blas. Changes in breeding sites among seasons indicate the need to develop comprehensive and simultaneous surveys throughout its breeding range to track global population trends. The apparent increase in population estimates stems more from recently discovered breeding sites than a population increase. The main threats to Olrog's Gulls are marine pollution and human disturbance of foraging areas. Increased awareness and improved spatial 
protection may suggest that breeding populations are receiving adequate attention, but efforts are needed to ensure that guidelines for their protection are included in protected area management plans and that these are implemented effectively. Future studies should develop recommendations to minimize conflicts between this threatened gull species and human populations by gathering information on temporal and spatial patterns of human activities in key gull foraging areas.

\section{Acknowledgements}

We thank Wildlife Conservation Society and Agencia Nacional de Promoción Científica y Tecnologica/PICT 33611 for financial support, Centro Nacional Patagónico (CONICET) for institutional support, and Soriano S.A. for logistical support. We thank Martín Sotelo, Marcos Magnanelli, Martín Carrizo and Valdemar Delhey for their help during aerial surveys, Nicolás Suárez and Laura Agüero for providing unpublished information, and Marcelo Davel (MD Helicópteros) for logistic support. We also thank the Buenos Aires and Chubut provincial authorities for the permits to work at protected areas, the Base Aeronaval Comandante Espora authorities for the permits to fly over restricted areas, and several volunteers for their help during field work.

\section{References}

Arias, A., Pereyra, M. and Marcovecchio, J. (2011) Multi-year monitoring of estuarine sediments as ultimate sink for DDT, $\mathrm{HCH}$, and other organochlorinated pesticides in Argentina. Environ. Monit. Assess. 172: 17-32.

Azpiroz, A. B. (2003) Aves del Uruguay. Lista e introducción a su biología y conservación. Montevideo, Uruguay: Aves UruguayGUPECA.

Beltrame, M. O., De Marco, S. G. and Marcovecchio, J. E. (2011) The burrowing crab Neohelice granulata as potential bioindicator of heavy metals in estuarine systems of the Atlantic coast of Argentina. Environ. Monit. Assess. 172: 379-389.

Berón, M. P. and Favero, M. (2009) Mortality of Olrog's Gulls Larus atlanticus associated with sport fishing activities. Hornero 24: 99-102.

Berón, M. P., Favero, M. and Gómez Laich, A. (2007) Use of natural and anthropogenic resources by the Olrog's Gull Larus atlanticus: implications for the conservation of the species in non-breeding habitats. Bird Conserv. Internatn. 17: 351-357.

BirdLife International (2012) Species fact sheet: Larus atlanticus. Downloaded from http://www.birdlife.org on 20/2/2012.

Botté, S. E., Freije, R. H. and Marcovecchio, J. E. (2008) Dissolved heavy metal (Cd, Pb, Cr, Ni) concentrations in surface water and porewater from Bahía Blanca estuary tidal flats. Bull. Environ. Contamination Toxicol. 79: 415421.

Burger, J. and Gochfeld, M. (2002) Effects of chemicals and pollution on seabirds. Pp. $485-525$ in E. A. Schreiber and J. Burger, eds. Biology of marine birds. Washington DC: CRC Press.

Daguerre, J. B. (1933) Dos aves nuevas para la fauna argentina. Hornero 5: 213-214.

Delhey, J. K. V., Petracci, P. F. and Grassini, C. (2001a) Hallazgo de una nueva colonia de la Gaviota de Olrog (Larus atlanticus) en la ría de Bahía Blanca, Argentina. Hornero 16: 39-42.

Delhey, J. K. V., Carrete, M. and Martínez, M. M. (2001b) Diet and feeding behavior of Olrog's gull Larus atlanticus in Bahía Blanca, Argentina. Ardea 89: 319-389.

Devillers, P. (1977) Observations at a breeding colony of Larus (belcheri) atlanticus. Gerfaut 67: 22-43.

Dias, R. A. and Maurício, G. N. (1998) Lista preliminar da avifauna da extremidade sudoeste do Saco da Mangueira e arredores, Rio Grande, Rio Grande do Sul. Atualidades Ornitológicas 86: 10-11.

Di Giacomo, A. (ed.) (2005) Áreas importantes para la conservación de las aves en Argentina. Sitios prioritarios para la conservación de la biodiversidad. Temas de Naturaleza y Conservación 5. Buenos Aires, Argentina: 
Aves Argentinas/Asociación Ornitológica del Plata.

Escalante, R. (1970) Aves marinas del Río de la Plata y aguas vecinas del Océano Atlántico. Montevideo, Uruguay: Barreiro y Ramos S.A.

Erwin, R., Allen, D. and Jenkins, D. (2003) Created versus natural coastal islands: Atlantic waterbird populations, habitat choices, and management implications. Estuaries and Coasts 26: 949-955.

Favero, M. (1991) Avifauna de la albúfera Mar Chiquita (Buenos Aires, Argentina). Ensamble táctico de aves que buscan el alimento desde el aire o desde perchas. Bolletino del Museo Regionale di Scienze Naturali di Torino 9: 287-298.

García Borboroglu, P. and Yorio, P. (2004) Habitat requirements and selection by Kelp Gulls in central and northern Patagonia, Argentina. Auk 121: 243-252.

García Borboroglu, P. and Yorio, P. (2007a) Breeding habitat requirements and selection by Olrog's Gull (Larus atlanticus), a threatened species. Auk 124: 12O-1212.

García Borboroglu, P. and Yorio, P. (2007b) Comparative habitat use by syntopic Kelp Gulls (Larus dominicanus) and Olrog's Gulls (L. atlanticus) in coastal Patagonia. Emu 107: 321-326.

Herrera, G., Punta, G. and Yorio, P. (2005) Diet specialization of Olrogss Gull Larus atlanticus during the breeding season at Golfo San Jorge, Argentina. Bird Conserv. Internatn. 15: 89-97.

La Sala, L. and Martorelli, S. (2010) First report of Olrog's Gull depredation by sympatric Kelp Gulls. Wilson J. Orn. 122: 188-189.

La Sala, L. F., Petracci, P. F., Smits, J. E., Botté, S. and Furness, R. W. (2011) Mercury levels and health parameters in the threatened Olrog's Gull (Larus atlanticus) from Argentina. Environ. Monit. Assess. 181: 1-11.

Lisnizer, N., García Borboroglu, P. and Yorio, P. (2011) Spatial and temporal variations in Kelp Gull population trends in northern Patagonia, Argentina. Emu 111: 259-267.

Marcovecchio, J. E., Moreno, V. and Pérez, A. (1988) Determination of heavy metal concentrations in the biota of Bahía Blanca. Argentina. Sci. Total Environ. 75: 181-190.
Menone, M. L., Miglioranza, K. S. B., Iribarne, O., Aizpún de Moreno, J. E. and Moreno, V. J. (2004) The role of burrowing beds and burrows of the SW Atlantic intertidal crab Chasmagnathus granulata in trapping organochlorine pesticides. Mar. Pollut. Bull. 48: 240-247.

Olrog, C. C. (1967) Breeding of the BandTailed Gull (Larus belcheri) on the Atlantic coast of Argentina. Condor 69: 42-48.

Pacheco, J. F., Olinto Branco, J. and de Queiroz Piacentini, V. (2009) Olrog's Gull Larus atlanticus in Santa Catarina, Brazil: northernmost occurrence and first state record. Cotinga 31: 80-81.

Petracci, P. F., Sotelo, M. R. and Díaz, L. I. (2008) Nuevo registro de nidificación de la Gaviota Cangrejera (Larus atlanticus) en la Reserva Natural Bahía Blanca, Bahía Falsa y Bahía Verde, Buenos Aires, Argentina. Hornero 23: 37-40.

Prefectura Naval Argentina (1998) Designación de zonas de protección especial en el litoral Argentino. Ordenanza $\mathrm{N}^{\circ} \quad 12 / 98$ (DPMA), Tomo 6: "Regimen para la Protección del Medio Ambiente". Buenos Aires, Argentina: Prefectura Naval Argentina.

Rábano, D., García Borboroglu, P. and Yorio, P. (2002) Nueva localidad de reproducción de la Gaviota de Olrog (Larus atlanticus) en la provincia de Buenos Aires, Argentina. Hornero 17: 105-107.

Silva Rodríguez, M. P., Favero, M., Berón, M. P., Mariano-Jelicich, R. and Mauco, L. (2005) Ecología y conservación de aves marinas que utilizan el litoral bonaerense como área de invernada. Hornero 20: 111-130.

Simonetti, P., Botté, S. E., Fiori, S. M. and Marcovecchio, J. E. (2012) Heavy-metal concentrations in soft tissues of the Burrowing Crab Neohelice granulata in Bahía Blanca Estuary, Argentina. Arch. Environ. Contam. Toxicol. 62: 243-253.

Sotelo, M. and Massola, M. V. (2008) Propuesta de Plan de Manejo de la Reserva Natural de uso múltiple Bahía Blanca, Bahía Falsa y Bahía Verde. Buenos Aires: Organismo Provincial para el Desarrollo Sostenible de la Provincia de Buenos Aires. Suárez, N., Retana, V. and Yorio, P. (2011) Temporal changes in diet and prey selection in the threatened Olrog's gull Larus atlanticus 
breeding in Southern Buenos Aires, Argentina. Ardeola 58: 35-47.

Suárez, N., Retana, V. and Yorio, P. (2012) Spatial patterns in the use of foraging areas and its relationship with prey resources in the threatened Olrog's gull (Larus atlanticus). J. Ornithol. 153: 861-871.

Whittacker, D. and Knight, R. L. (1998) Understanding wildlife responses to humans. Wildl. Soc. B. 26: 312-317

Yorio, P. M. and Harris, G. (1992) Actualización de la distribución reproductiva, estado poblacional y de conservación de la gaviota de Olrog (Larus atlanticus). Hornero 13: 200-202.

Yorio, P., Rábano, D. and Friedrich, P. (2001b) Habitat and nest site characteristics of Olrog's Gull Larus atlanticus breeding at Bahía San Blas, Argentina. Bird Conserv. Internatn. 11: 27-34.

Yorio, P., Bertellotti, M., Gandini, P. and Frere, E. (1998) Kelp gulls Larus dominicanus breeding on the argentine coast: population status and relationship with coastal management and conservation. Mar. Orn. 26: $11-18$.

Yorio, P., Frere, E., Gandini, P. and Conway, W. (1999) Status and conservation of seabirds breeding in Argentina. Bird Conserv. Internatn. 9: 299-314.

Yorio, P., Frere, E., Gandini, P. and Schiavini, A. (2001a) Tourism and recreation at seabird breeding sites in Patagonia, Argentina: current concerns and future prospects. Bird Conserv. Internatn. 11: 231-245.

Yorio, P., Quintana, F., Gatto, A., Lisniser, N. and Suárez, N. (2004) Foraging patterns of breeding Olrog's Gull at Golfo San Jorge, Argentina. Waterbirds 27: 193-199.

Yorio, P., Punta, G., Rabano, D., Rabuffetti, F., Herrera, G., Saravia, J. and Friedrich, P. (1997) Newly discovered breeding sites of Olrog's Gull Larus atlanticus in Argentina. Bird Conserv. Internatn. 7: 161-165.

Zalba, S. M., Nebbia, A. J. and Fiori, S. M. (2008) Propuesta de Plan de Manejo de la Reserva Natural de Uso Múltiple Bahía San Blas. Bahía Blanca, Argentina: Universidad Nacional del Sur.

\section{PABLO YORIO*}

Centro Nacional Patagónico (CONICET), Blvd. Brown 2915, (9120) Puerto Madryn, Chubut, Argentina, and Wildlife Conservation Society, Amenabar 1595, P 2, Of. 19, (C1426AKC) Ciudad de Buenos Aires, Argentina.

\section{PABLO GARCÍA BORBOROGLU}

Centro Nacional Patagónico (CONICET), Blvd. Brown 2915, (9120) Puerto Madryn, Chubut, Argentina, and Department of Biology, University of Washington, Box 35180o, Seattle, WA 98195-1800, USA.

\section{PABLO PETRACCI}

Cátedra Zoología III Vertebrados, Facultad de Ciencias Naturales y Museo, Universidad Nacional de la Plata, Paseo del Bosque s/n, (1900) La Plata, Buenos Aires, Argentina.

${ }^{*}$ Author for correspondence; e-mail: yorio@cenpat.edu.ar

Received 5 June 2012; revision accepted 23 October 2012;

Published online 28 March 2013 